\title{
Influence of Micro Economic and Macro Economic on Yield to Maturity of ljarah Sukuk Corporation Year 2014-2017
}

\section{Hana Khaiririah Ulfah, Kusnendi, Suci Aprilliani, and Fitranty Adirestuty}

Economics and Islamic Finance Department, Universitas Pendidikan Indonesia, Jl. Dr. Setiabudhi No. 229, Bandung City, Indonesia

\section{Abstract}

The purpose of this research is to examine the influence of micro economic factor which is described with profitability and firm size, and macro economic factor which is described with $\mathrm{BI}$-Rate and Inflation on the yield to maturity of sukuk ijarah. The yield to maturity of sukuk that will be received by investors illustrates the level of investor profit but the yield level also describes the level of risk borne by investors. This research is useful for investors in considering for profit and risk to be received. This research was conducted on all companies listed on the Indonesia Stock Exchange in the 2014-2017

Corresponding Author: Hana Khaiririah Ulfah hanaulfah@gmail.com

Received: 10 February 2019 Accepted: 14 March 2019 Published: 28 March 2019

Publishing services provided by Knowledge E

(c) Hana Khaiririah Ulfah et al. This article is distributed under the terms of the Creative Commons Attribution License, which permits unrestricted use and redistribution provided that the original author and source are credited.

Selection and Peer-review under the responsibility of the ICIEBP Conference Committee. period which issued sukuk ijarah and published its financial statements during the study period. The research samples is 68 ijarah sukuk.The data analysis technique used in this study is panel data regression with fixed effect model. The results showed that profitability projected with Return on Asset and firm size did not affect to yield to maturity of sukuk ijarah, BI-Rate variable had a positive and significant effect on yield to maturity of sukuk

Keywords: Profitability (ROA), Firm size, BI-Rate, Inflation and Yield to Maturity and inflation had a negative effect on yield of ijarah sukuk.

\section{Introduction}

One investment instrument that is developing in the Islamic capital market is corporate sharia bonds, better known as corporate sukuk. Since the issuance of the Dewan Syariah Nasional (DSN) the Majelas Ulama Indonesia (MUI) in 2002 issued Fatwa No.32 / DSNMUI / IX / 2002 concerning Sharia Bonds, and then sukuk began to grow and develop alongside conventional bonds. According to Otoritas Jasa Keuangan Regulation number 18 / POJK.04 / 2015, Sukuk are Sharia Securities in the form of certificates or proof of ownership that are of equal value and represent an inseparable or undivided share, for the underlying assets (Otoritas Jasa Keuangan, 2015) 
Yield to maturity reflects returns with a compound margin level (Tandelilin, 2017). According to the data obtained from (Indonesia Bond Pricing Agency, 2018), the average level of Yielad to Maturity (YTM) in all ljarah sukuk decreased in 2014-2017. With the decline in the YTM average this indicates that many YTM sukuk ijarah levels have decrease so that the level of profit obtained when the sukuk is purchased at the present time will get a lower compound return.

In (Manan, 2017) explained one of the goals of someone investing is to get a decent life in the future. That way someone who invests is very concerned about the level of return that he gets in the future. However, theoretically risks and returns are linear relationships. This means that the greater the risk of one asset, the greater the expected return on the asset and the smaller the risk, the smaller the return (Tandelilin, 2017). So that this research is very useful for investors, especially investors with the type of risk averse.

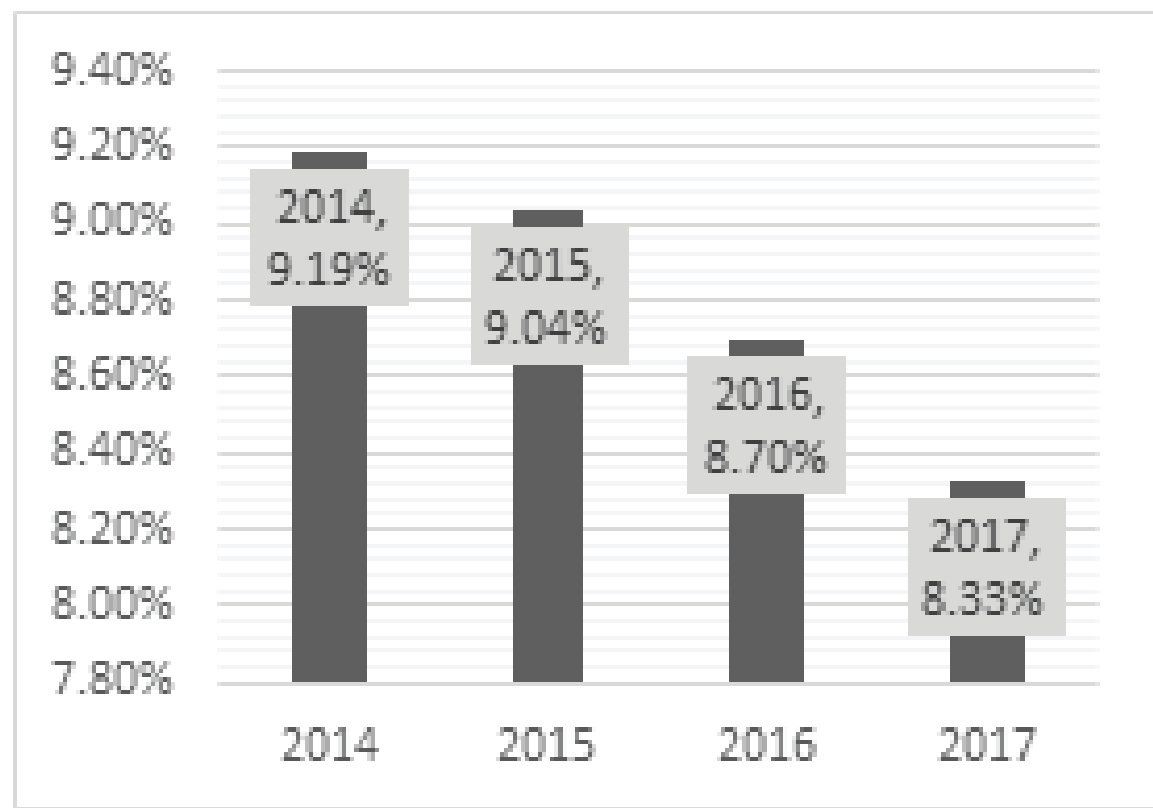

Figure 1: The average Yield to Maturity of all sukuk ljarah in Indonesia 2014-2017 (Source: (Indonesia Bond Pricing Agency, 2018)).

In (Rahardjo, 2003) stated in investing to get profits such as in the stock market or in the bond market. there is always a potential risk of loss. Therefore, investment risk analysis is needed, including microeconomic analysis that is described by the company's conditions and macroeconomic analysis.From several previous studies in examining the factors that affect the yield of ijarah sukuk and bonds with a fix rate interest using micro variants illustrated by the issuer's financial conditions and macro variables described in the Indonesian economy. 
Profitability ratio is a ratio to assess a company's ability to seek profits (Kasmir, 2013). In some studies profitability ratios have an influence on the yield to maturity of sukuk or yield to maturity bonds with types of fixed returns, the study was conducted by (Abundanti, 2015) and, but the research conducted by (Yahya, 2017) shows no influence on profitability variables. In addition to the profitability variable, the research conducted by (Ibrahim, 2008) and (Melati, 2013) the size of the company depicted by the total assets owned has influence on the yield of sukuk, but the research conducted by (Situmorang, 2017) shows that variable size no effect on yield.

Inflation is a macro variable that has a large influence on economic activities in the capital market. In (Tandelilin, 2017) explained that inflation risk will cause a decrease in real income. In the context of debt securities, an increase in inflation will cause a decrease in real value of the yield of debt securities obtained by investors during the age of the bonds (Haryanto, 2012).in the research conducted by (Yahya, 2017) and (Prasetiyono, 2014). Proving that there is influence of inflation on yield to maturity of sukuk and yield to maturity of bonds with fixed return. However, the research conducted by (Oktavian, 2015) shows that inflation has no effect on yield.

BI-Rate is one of the macro variables that addresses its influence on the yield to maturity of sukuk and bonds with fixed return. According to (Hermawan, 2006) interest rates will influence the decision making of capital owners whether he will invest in real assets or in financial assets. The financial assets in question are securities including sukuk and stock. According to (Nanaeva, 2010). The risk level of returns for sukuk is similar to the risk of conventional bonds with a fixed interest rate, due to the fact that most of the problems of modern sukuk have fixed payments. So, when the market interest rate rises, the value of the sukuk falls. In several studies the BI Rate variable has an influence on the yield of sukuk and bonds with fixed rate, namely the research conducted by (Prasetiyono, 2014) and (Wida Purwidianti, 2017).

\section{Literatur Review}

\subsection{Sukuk ljarah}

According to (Manan, 2017) Sukuk ljaraha is a bond based on the ljarah Agreement. The ljarah contract is a type of contract to take advantage by replacing it. This means that the owner of the property gives the right to use objects that are transacted through temporary control or borrowing objects with certain benefits by paying compensation to the owner of the object. 
Sukuk ljarah is considered a flexible structure, and can be used for various financing needs. In addition, the Sukuk ljarah is truly negotiable and can therefore be traded on the secondary market, because this Sukuk certificate represents ownership in real assets. As a result, many Sukuk publishers chose the ljarah structure. Sukuk ljarah is issued by companies, governments, Government Organizations and other organizations (Nisar, 2010).

\subsection{Yield to maturity}

Yield in (Samsul M., 2006) is a return on investment in bonds which is expressed as a percentage. There are several calculation methods for yield, nominal yield, current yield, yield to maturity and yield to call.

Yield to maturity is most widely used as a measure of yield because it can reflect returns with compound interest rates that investors expect if the two assumptions required can be fulfilled. The first assumption is that investors will retain the bonds until maturity. The second assumption is that investors reinvest the income earned from bonds at the yield to maturity level. If both of these assumptions are met, the expected yield to maturity will be the same as realized yield. If the coupon income is not invested at the same level with the Yield to maturity, the yield to maturity obtained will be smaller or greater than the promised yield. Calculation formula for yield to maturity uses the Equation Approximation method (Tandelilin, 2017).

$$
Y T M=\frac{C_{1}+\frac{P_{p}-P}{n}}{\frac{P_{p}+P}{2}}
$$

$$
\begin{aligned}
& \text { YTM = Yield to maturity } \\
& P=\text { Current bond price } \\
& n=\text { Total of years up to maturity bonds / sukuk } \\
& \mathrm{Ci}=\text { Payment of coupons for each bond year } \\
& \mathrm{Pp}=\text { Par value of bonds / sukuk }
\end{aligned}
$$

\subsection{Profitability}

Profitability ratio is a ratio to assess a company's ability to seek profits. This ratio also gives a measure of the management effectiveness of a company. This is indicated by 
profits generated from sales and investment income. The point is the use of this ratio shows the efficiency of the company (Kasmir, 2013).

$\frac{\text { Net Income }}{\text { Total Asset }}$

According to research conducted by (Widyarti, 2010) profitability has a negative effect because good company performance indicates that the company has good prospects to invest in the hope that the possibility of default / interest paying interest and principal on the issued debt securities will be low. But as compensation for the company's good performance, the company will offer lower yields, because the default risk that investors will face is lower.

\subsection{Firm size}

In (Sawir, 2008) Size of a company can determine the level of ease for companies to obtain funds from the capital market. Small companies generally lack access to organized capital markets, both for bonds and stocks. According to (Sujianto, 2011) company size describes the size of a company as indicated by total assets, total sales, average total asset sales, and average total assets in this study total assets projected with total assets.

\section{Firm Size $=$ Ln Total Asset}

In research conducted (Ibrahim, 2008) size of the company has a negative influence, because companies that are in a growing position use more funds or cash flow to invest in both current and non-current assets, investment in the development of technology and products, so the possibility of risk failure in principal payments and bond coupons is very high. This can lead to lower bond ratings so that the company will pay high yield to maturity to attract investor interest. Conversely, the company at the mature stage will reduce investment and have a smooth cash flow so that it can pay interest and principal loans smoothly. This tends to make risk at this stage lower and the yield to maturity of the bonds offered is low.

\subsection{BI rate}

The BI Rate is a policy interest rate that reflects the monetary policy stance set by Bank Indonesia and is publicly announced. The BI Rate is announced by the Bank Indonesia Board of Governors every monthly Board of Governors Meeting and implemented in 
monetary operations conducted by Bank Indonesia through liquidity management in the money market to achieve the operational objectives of monetary policy. The operational target of monetary policy is reflected in the development of Overnight Interbank Money Market interest rates (Bank Indonesia, 2016).

According to (Nanaeva, 2010) The risk level of returns for sukuk is similar to the risk of conventional bonds with a fixed interest rate, due to the fact that most of the problems of modern sukuk have fixed payments. So, when the market interest rate rises, the value of the sukuk falls.

In a study conducted (Wida Purwidianti, 2017) the influence of the BI Rate on sukuk yields has a positive relation because investment in deposits or Bank Indonesia Certificates (SBIs) investment in that produces risk-free interest so that management is very easy and tends to be safe (Samsul, 2006). Investments in debt securities contain a variety of risks in management such as the risk of loss of more profitable investment opportunities (opportunity costs), the existence of principal repayment failures or the default payment of yields on bonds. Therefore, investors will expect bond yields that are higher than the deposit rate so that investment remains profitable. Therefore, if the interest rate increases, the amount of yield required by investors will increase (Ibrahim, 2008).

\subsection{Inflation}

According to (Hasyim, 2016) inflation is all economic symptoms that show a general increase in price levels in a sustainable manner. Inflation conditions that increase prices in general and continuously. If only one or two items rise, that is not inflation. Temporary price increases, for example price increases due to seasonality, ahead of holidays, disasters, etc., are not called inflation.

In the research conducted by (Yahya, 2017), there is a positive influence the inflation variable on yield. This is because in (Tandelilin, 2017) it is explained that inflation risk will lead a decrease in real income. In the context of debt securities, an increase in inflation will lead a decrease in real value from the yield income of bonds obtained by investors during the life of the bonds. By describing the high level of risk, the expected yield to maturity of investors is higher. 


\section{Methodology}

Population in this study was sukuk circulating in 2014-2017. By using purposive sampling technique, the sample used in this study is sukuk issued by companies circulating in 2014-2017 and sukuk issuers have published financial reports. So that 68 ijarah sukuk.

Data management techniques use panel data regression with a fixed effect model. The data sources in this study are the Indonesia Bond Pricing Agency, the Financial Services Authority, the Indonesia Stock Exchange and the Issuer's Financial Report.

\section{Result}

This study will examine the effect of micro and macro variables on the yield to maturity of sukuk ijarah. the micro variable used is the condition of the issuer or company issuing sukuk, profitability as measured by Retrun on Assets and company size measured by total assets. Meanwhile the macro variable used is the level of the BI Rate and inflation.

Based on the chow test, it was found that the fixed effect model was better than the common effect model and based on the results of the hausman test it was found that the fixed effect model was better used than the random effect model. Thus the model used is a fixed effect model, so that the regression test will get a t test which will test the partial influence of the variables. The results of the $t$ test can be seen in tabel 1 .

TABLE 1: Test $\mathrm{t}$.

\begin{tabular}{|c|c|c|c|}
\hline Variabel & t Hitung & t Tabel & Nilai Prob $t$ \\
\hline Profitabilitas & 1.406424 & 1.65630 & 0.1643 \\
\hline $\begin{array}{l}\text { Ukuran } \\
\text { Perusahaan }\end{array}$ & -1.539395 & 1.65630 & 0.1285 \\
\hline BI Rate & 12.63860 & 1.65630 & 0.0000 \\
\hline Inflasi & -3.360610 & 1.65630 & 0.0013 \\
\hline
\end{tabular}

There is no influence given the variable profitability projected with Return on Assets (ROA) on ijarah sukuk yields. According to (Yahya, 2017) investing in sukuk which is basically a debt investor is not racing against the profitability ratio owned by a company because profitability has more influence on stock returns than bond returns (bond yield) in long-term investments, because payment of compensation for bonds is considered as costs (interest costs) and cost calculations are made before the calculation of profits, while payment of compensation for shares (dividends) is carried out after the calculation 
of profits so that profitability does not affect the yield to maturity of bonds. The results of this study are in line with the research conducted by (Yahya, 2017).

Company size in research projected with total assets owned by the company. the results of this study indicate that there is no effect on the variable size of the company on the ijarah sukuk yield. the results of this study are in line with the research (Situmorang, 2017) where the size of the company does not have an effect on the sukuk yield published. according to (Situmorang, 2017) there is no influence of company size on yield to maturity because investors do not consider the size of the company as the basis for investment. adequate ability of the company to pay its obligations and Indonesian market conditions that are considered by investors in making investments. Meanwhile in (Epi, 2017) explained the greater the assets held, the more complex the agency problem with the shareholders faced. thus increasing the company's burden. so that the size of a large company does not guarantee the company is far from risk. meanwhile in (Abundanti, 2015) explained investors are more likely to see sukuk ratings to comprehensively assess before investing.

The results of this study indicate that there is a positive and significant influence that gives the $\mathrm{BI}$ Rate to the yield of ijarah sukuk. In (Prasetiyono, 2014) presents in the results of his research that the $\mathrm{BI}$ rate has an effect on the size of the yield, this is because if the $\mathrm{BI}$ rate increases it will be responded to by the increase in the level of return that investors impose because bond prices tend to fall due to the $\mathrm{BI}$ interest rate increase, with in other words if the $\mathrm{BI}$ rate increases, the yield to maturity required by investors will also increase. According (Hartono, 2012) in these conditions, the bond market price will decrease because investors who have fixed return bonds (including sukuk ijarah) only get a fixed coupon rate, even though the rate of return implied on the bonds has increased. The results of this study are in line with the research conducted by (Ibrahim, 2008), (Prasetiyono, 2014) and (Wida Purwidianti, 2017).

The results of this study indicate that there is a negative and significant influence given the variable inflation on sukuk yield. According to (Putong, 2002),,inflation is low, namely inflation which is less than $10 \%$. Low and stable inflation is a basic prerequisite in achieving sustainable economic growth and community welfare (Hutabarat, 2005). With the existence of mild inflation, has a positive influence that can drive the economy, one of them is the increase in national income (Rasud Changes in economic conditions such as increasing GDP, high GDP indicate that existing investments have a low level of risk while sukuk or bonds that have low risk will give low yields (Prasetiyono, 2014). In (Sudiyatno, 2010) explained that macroeconomic fundamental factors are a reflection 
of systematic risk. Worsening macroeconomic conditions will increase systematic risk which can reduce company performance or increase.

The results of the $F$ test conducted show that the four variables simultaneously influence yield, where $F$ table $<F$ counts with prob. 0.00000. In addition to $t$ test and $F$ test panel data regression results also show the value of the coefficient of determination (R2) explains how much the total percentage of the dependent variable explained by the model, the greater the R2 value the greater the influence of the model in explaining the dependent variable. 22 values range from 0 to 1 .

TABLE 2: Uji F.

\begin{tabular}{|l|r|r|}
\hline F Tabel & F Hitung & Prob. Uji F \\
\hline $\mathbf{2 . 4 4}$ & 5.911783 & 0,00000 \\
\hline Source: Research Results (2018) & \\
\hline
\end{tabular}

Based on the regression results the level of closeness of the effect of the independent variables on the dependent variable is 72 percent while the remaining 28 percent is influenced by other factors not included in the regression model.

\section{Conclusion}

The conclusions in this study indicate that the variable profitability and firm size do not affect yield, the BI Rate variable gives a significant positive effect on sukuk yield and the inflation variable gives a negative and significant influence on the ijarah sukuk yield.

From the results of these studies can be used for investors to give consideration to investors in investing sukuk. Where the yield to maturity in ijarah sukuk is influenced by two macro variables, namely the $\mathrm{BI}$ rate and inflation variables so that investors can consider the returns and risks that will be accepted if they invest their money in sukuk instruments.

Suggestions in further research should use other microeconomic variables that show the performance of the issuer against debt debt such as the Debt to Equity Ratio. And the use of more variable macro variables such as Product Domestic Income (GDP)u, 2018).

\section{References}

[1] Abundanti. (2015). Variabel-VAriabel yag Mempengaruhi Yield Obligasi pada Perusahaan yang Terdaftar di Bursa Efek di Indonesia. E-Jurnal Manajemen Unud, 
Vol. 4, No.11 .

[2] Bank Indonesia. (2016). BI Rate. Retrieved Juli 16, 2018, from https://www.bi.go.id/id/ moneter/bi-rate/penjelasan/Contents/Default.aspx

[3] Epi, Y. (2017). Pengaruh Ukuran Perusahaan, Struktur Kepemilikan, Manajerial dan Manajemen Laba Terhadap Kinerja Perusahaan Property dan Real Estate yang Terdaftar di Bursa Efek Indonesia. Riset \& Jurnal Akunta .

[4] Hartono, S. H. (2012). Analisis Faktor-Faktor yang mempengaruhi Yield Obligasi. Dipoegoro Journal Of Management .

[5] Haryanto, S. H. (2012). Analisis Faktor-Faktor yang memepengaruhi Yield Obligasi Korporasi. Diponegoro Journal of Management .

[6] Hasyim, A. I. (2016). Ekonomi Makro. Jakarta: Prenadamedia Group.

[7] Hermawan, D. (2006). Pasar Finansial dan Lembaga-Lembaga Finansial. Jakarta: Bumu Aksara.

[8] Hutabarat. (2005). Determinan Inflasi Indonesia. Occasional Paper No OP/06/2005 Bank Indonesia .

[9] Ibrahim, H. (2008). Pengaruh Tingkat Suku Bunga, Peringkat Obligasi, Ukuran Perusahaan Dan Der Terhadap Yield To Maturity Obligasi Korporasi Di Bursa Efek Indonesia Periode Tahun 2004-2006 . TESIS Program Studi Magister Manajemen Universitas Diponegoro .

[10] Indonesia Bond Pricing Agency. (2018). Yield To Maturity Sukuk ljarah dan Mudharabah. Jakarata: Indonesia Bond Pricing Agency.

[11] Kasmir. (2013). Analisis Laporan Keuangan. Jakarta: Rajawali Pers.

[12] Manan, A. (2017). Aspek Hukum Dalam Penyelenggaraan Investasi di Pasar Modal Syariah. Jakarta: Fajar Intan Pratama Mandiri.

[13] Melati, A. (2013). Faktor Faktor yang Mempengaruhi Tingkat Sewa Sukuk ljarah. Accounting Analysis Journal , 233.

[14] Nanaeva, Z. K. (2010). How risky sukuk are: comparative analysis of risks associated with sukuk and conventional bonds. Dissertation submitted in partial fulfillment of the degree of MSc in Finance and Banking .

[15] Nisar. (2010). How Sukuk works: Introduction, structuring and application of Sukuk bonds . Retrieved 2018, from https://ifresource.com/2010/04/27/how-sukukworksintroduction-structuring-and-application-of-sukuk-bonds/

[16] Oktavian, O. (2015). Pengaruh Tingkat Inflasi, DER, Likuiditas Obligasi dan Rating terhadap Yield Obligasi Korporasi Yang Terdaftar Di Bursa Efek Indonesia (BEI) Tahun2009-2012. JOM FEKON Vol.2 . 
[17] Otoritas Jasa Keuangan. (2015). Peraturan Otoritas Jasa Keuangan Nomor 59/POJK.04/2015.

[18] Prasetiyono, T. A. (2014). Analisis Faktor-Faktor Yang Mempengaruhi Yield Obligasi Konvensional Di Indonesia (Studi Kasus Pada Perusahaan Listed di BEI). Jurnal Studi Manajemen \& Organisasi .

[19] Putong, I. (2002). Pengantar Ilmu Ekonomi Mikro dan Makro. Jakarta: Ghalia Indonesia.

[20] Rahardjo, S. (2003). Panduan Investasi Obligasi. Jakarta: Gramedia Pustaka Utama.

[21] Rasudu, N. A. (2018). Pengaruh Inflasi, Suku Bunga, Kurs, Coupon Rate, Dan Likuiditas Obligasi Terhadap Harga Obligasi Pemerintah Ri (Surat Utang Negara) Periode 20142016. Tesis .

[22] Samsul, M. (2006). Pasar Modal \& Manajemen Portofolio. Erlangga.

[23] Sawir, A. (2008). Analisis Kinerja Keuangan dan Perencanaan Keuangan. Jakarta: PT.Gramedia Pustaka Utama.

[24] Situmorang, B. (2017). Pengaruh Peringkat Obligasi, Debt to Equity Ratio dan Ukuran Perusahaan Terhadap Yield to Maturity Obligasi Korporasi dengan Bunga SBI Sebagai Variabel Moderating . Jurnal Terapan Manajemen dan Bisnis , 42.

[25] Sudiyatno, B. (2010). Peran Kinerja Perusahaan dalam Menentukan Pengaruh Faktor Fundamental Makroekonomi, Risiko Sistematis, dan Kebijakan Perusahaan Terhadap Nilai Perusahaan. Program Pacasarjana Universitas Diponegoro .

[26] Sujianto. (2011). Dasar-Dasar Manajemen Keuangan. Yogyakarta: BPFE.

[27] Tandelilin, E. (2017). Pasar Modal Manajemen POrtofolio dan Investasi. Depok: Kanisius.

[28] Wida Purwidianti, P. P. (2017). Pengaruh Peringkat Obligasi,Tingkat Suku Bunga Sertifikat Bank Indonesia,Rasio Leverage,Ukuran Perusahaan, Umur Obligasi,Dan Tingkat Inflasi Pada Imbal Hasil Obligasi Korporasi Dibursa Efek Indonesia. Jurnal Manajemen dan Bisnis MEDIA EKONOMI Volume XVII .

[29] Widyarti, H. H. (2010). Analisis Pengaruh Tingkat Suku Bunga Likuiditas Obligasi,Rating Obligasi, Dan Return On Equity Perusahaan Teriiadap Yield Spread Obligasi Perusahaan (Studi Komparasi Obligasi Perusahaan Finansial dan NonFinansial yang Tercatat di Bursa Efek. Jurnal Studi Manaiemen \& Organisasi Vol.7 No.l , 1-28.

[30] Yahya, W. F. (2017). Analisis Faktor - Faktor Yang Mempengaruhi Yield Obligasi . Jurnal IImu dan Riset Manajemen Volume 6, Nomor 8. 